\title{
Semiotic narratives and french home appliances
}

\section{Robert L. Frost}

\section{OpenEdition}

\section{Journals}

Electronic version

URL: https://journals.openedition.org/tc/663

DOI: $10.4000 /$ tc. 663

ISSN: 1952-420X

\section{Publisher}

Éditions de l'EHESS

\section{Printed version}

Date of publication: 1 May 1993

ISSN: 0248-6016

\section{Electronic reference}

Robert L. Frost, "Semiotic narratives and french home appliances", Techniques \& Culture [Online], 19 1993, Online since 10 January 2006, connection on 29 September 2022. URL: http:// journals.openedition.org/tc/663 ; DOI: https://doi.org/10.4000/tc.663

This text was automatically generated on 29 September 2022

All rights reserved 
Semiotic narratives and french home appliances

Robert L. Frost 